\title{
Acrolein exposure suppresses antigen-induced pulmonary inflammation
}

\author{
Page C Spiess ${ }^{1}$, David Kasahara ${ }^{1,3}$, Aida Habibovic ${ }^{1}$, Milena Hristova', Matthew J Randall ${ }^{1}$, Matthew E Poynter ${ }^{2}$ \\ and Albert van der Vliet ${ }^{1^{*}}$
}

\begin{abstract}
Background: Adverse health effects of tobacco smoke arise partly from its influence on innate and adaptive immune responses, leading to impaired innate immunity and host defense. The impact of smoking on allergic asthma remains unclear, with various reports demonstrating that cigarette smoke enhances asthma development but can also suppress allergic airway inflammation. Based on our previous findings that immunosuppressive effects of smoking may be largely attributed to one of its main reactive electrophiles, acrolein, we explored the impact of acrolein exposure in a mouse model of ovalbumin (OVA)-induced allergic asthma.
\end{abstract}

Methods: C57BL/6 mice were sensitized to ovalbumin (OVA) by intraperitoneal injection with the adjuvant aluminum hydroxide on days 0 and 7, and challenged with aerosolized OVA on days 14-16. In some cases, mice were also exposed to 5 ppm acrolein vapor for 6 hrs/day on days 14-17. Lung tissues or brochoalveolar lavage fluids (BALF) were collected either 6 hrs after a single initial OVA challenge and/or acrolein exposure on day 14 or 48 hrs after the last OVA challenge, on day 18. Inflammatory cells and Th1/Th2 cytokine levels were measured in BALF, and lung tissue samples were collected for analysis of mucus and Th1/Th2 cytokine expression, determination of protein alkylation, cellular thiol status and transcription factor activity.

Results: Exposure to acrolein following OVA challenge of OVA-sensitized mice resulted in markedly attenuated allergic airway inflammation, demonstrated by decreased inflammatory cell infiltrates, mucus hyperplasia and Th2 cytokines. Acrolein exposure rapidly depleted lung tissue glutathione (GSH) levels, and induced activation of the Nrf2 pathway, indicated by accumulation of Nrf2, increased alkylation of Keap1, and induction of Nrf2-target genes such as HO-1. Additionally, analysis of inflammatory signaling pathways showed suppressed activation of NF-KB and marginally reduced activation of JNK in acrolein-exposed lungs, associated with increased carbonylation of RelA and JNK.

Conclusion: Acrolein inhalation suppresses Th2-driven allergic inflammation in sensitized animals, due to direct protein alkylation resulting in activation of Nrf2 and anti-inflammatory gene expression, and inhibition of NF-KB or JNK signaling. Our findings help explain the paradoxical anti-inflammatory effects of cigarette smoke exposure in allergic airways disease.

Keywords: Cigarette smoke, Electrophile, Inflammation, Asthma, COPD, Nrf2, NF-kB, JNK

\section{Background}

Cigarette smoking remains prevalent worldwide, and is among the main preventable causes of pulmonary and cardiovascular disease and death. In addition to strong links with lung cancer, cigarette smoking or exposure to environmental tobacco smoke are also associated with chronic pulmonary inflammatory diseases such as COPD and asthma [1,2]. Strong associations exist between

\footnotetext{
* Correspondence: albert.van-der-vliet@uvm.edu

'Department of Pathology, College of Medicine, D205 Given Building, 89

Beaumont Ave, Burlington VT 05405, USA

Full list of author information is available at the end of the article
}

cigarette smoking and the frequency and severity of several respiratory tract infections, such as influenza or tuberculosis, due to its impact on the immune system $[3,4]$. Additionally, altered immune responses and local oxidative stress within the airways of smokers may be responsible for increased incidence and persistence of respiratory infections and chronic inflammation, which ultimately contribute to the development and/or exacerbations of COPD and allergic airway inflammation [5-7]. Yet, the effects of tobacco smoke on the development and severity of allergic asthma are not as clear. The 
association between passive smoke exposure and childhood asthma is relatively well established [8-10]. However, other studies have failed to demonstrate an association between smoking and asthma, and smokers were in some cases found to be at lower risk of developing asthma compared to nonsmokers or ex-smokers [11,12]. Studies in animal models confirm this dichotomy, and demonstrate that cigarette smoke (CS) can promote allergic sensitization and exacerbate allergic responses [13-15], but can also attenuate allergic inflammation and airway hyperresponsiveness during allergen challenge of previously sensitized animals [16-19].

Although the biological effects of CS are due to many diverse mechanisms, several studies invoke the important contribution of CS-derived reactive oxygen species, primarily based on observations of protective effects of thiol-based antioxidants $[2,20,21]$. However, the main thiol-reactive agents within tobacco smoke are electrophilic aldehydes and ketones, among which acrolein is believed to be of primary importance [2,22-24]. Mainstream CS contains levels of acrolein over 90 ppm [23], and measurements of acrolein levels in airway secretions or exhaled breath condensate from smokers suggest it can reach $1-10 \mu \mathrm{M}$ in the lung $[25,26]$. At doses ranging from 0.2-6 ppm, the effects of acrolein vapor mimic those of CS in inhalation studies [27-29]. Indeed, acrolein exposure exerts suppressive effects on the immune system and inhibits alveolar macrophage responses and function [29-31]. These anti-inflammatory and immunosuppressive effects of acrolein are thought to be due to inhibition of redox-sensitive transcription factors, such as nuclear factor-kappa B (NF-kB) and activator protein-1 (AP-1), through direct alkylation of proteins involved in these pathways [32-36]. Furthermore, our recent studies indicate that acrolein exposure alters alveolar macrophage responses by suppressing classical "M1" macrophage responses and favoring alternative "M2" polarization programs, consistent with similar observations in smokers [37]. Additionally, anti-inflammatory effects of various alkylating agents, such as sulforaphane, curcumin and $15 \mathrm{~d}-\mathrm{PGJ} \mathrm{J}_{2}$, have been linked to alkylation of kelch-like ECH-associated protein 1 (Keap1), and subsequent activation of the transcription factor Nuclear factor (erythroidderived 2)-like 2 (Nrf2) (reviewed in [38]), which results in the induction of a number of antioxidant and immunosuppressive genes, including heme oxygenase-1 (HO-1) and glutamate-cysteine ligase (GCL), the rate limiting enzyme in glutathione (GSH) synthesis [39].

Although epidemiological evidence suggests an association between acrolein exposure and increased asthma risk [40], limited reports have addressed the direct role of acrolein in allergic airway inflammation [41]. The studies presented herein were designed to explore the impact of acrolein in a mouse model of allergic asthma. Our findings indicate that acrolein exposure (5 ppm, 6 hrs/day) during allergen challenge markedly attenuates Th2-driven inflammatory responses by inhibiting redox-sensitive inflammatory signaling pathways including NF- $\mathrm{kB}$ and by activating Nrf2 and inducing anti-inflammatory genes such as HO-1.

\section{Methods}

\section{Animals and reagents}

Male 6-8 week old C57BL/6 mice were purchased from Charles River (Saint Constant, Quebec). All animal studies were approved by the Institutional Animal Care and Use Committee at the University of Vermont. All chemicals were purchased from Sigma-Aldrich (St. Louis, MO) unless otherwise indicated.

\section{Ovalbumin sensitization and challenge}

Mice were injected intraperitoneally (i.p.) with $20 \mu \mathrm{g}$ of ovalbumin (OVA) solubilized in sterile phosphate buffered saline (PBS) in a 1:1 mixture with the adjuvant aluminum hydroxide (Alum) (Imject ${ }^{\circ}$ Alum; Thermo Scientific, Rockford, IL) on days 0 and 7 to sensitize to OVA (OVA group) (Figure 1). Sham-sensitized mice received PBS in Alum (Sham group). All mice were exposed to aerosolized 1\% OVA solution in sterile PBS for 30 min on days 14-16 and harvested either $6 \mathrm{hrs}$ after the initial challenge on day 14 or on day $18,48 \mathrm{hrs}$ after the last challenge.

\section{Acrolein exposures}

Mice were placed in a $2 \mathrm{~L}$ glass chamber situated in a chemical fume hood and exposed to $5 \mathrm{ppm}\left(11.5 \mathrm{mg} / \mathrm{m}^{3}\right)$ of acrolein vapor for 6 hrs/day, on days 14-17 (Figure 1). Vaporized acrolein was diluted with room air to $5 \mathrm{ppm}$ and passed through the chamber at $5 \mathrm{~L} / \mathrm{min}$. The acrolein vapor concentration was continuously monitored using an infrared sensor (Miran SapphIRe model M205, Thermo Scientific, Franklin, MA). Control mice were exposed to room air at $5 \mathrm{~L} / \mathrm{min}$ for $6 \mathrm{hrs} /$ day, on days 14-17.

\section{Blood collection and OVA-specific lgG1 assay}

Mice were sacrificed by i.p. injection of sodium pentobarbital. Following euthanasia, blood was collected via cardiac puncture into serum separator tubes, centrifuged at 3,000 rpm for $10 \mathrm{~min}$, and serum was kept frozen at $-80^{\circ} \mathrm{C}$ until analysis. An ELISA for OVA-specific IgG1 was performed as previously described [42].

\section{BALF collection and BAL cell counts}

After tracheal cannulation, lungs were lavaged 3 times with $500 \mu \mathrm{L}$ PBS, and lavage fluids were kept on ice until processing. Lung lavage samples were centrifuged at $1500 \mathrm{rpm}$ for $5 \mathrm{~min}$ at $4^{\circ} \mathrm{C}$. The supernatant was frozen in liquid $\mathrm{N}_{2}$ and the cell pellet was resuspended in $400 \mu \mathrm{L}$ PBS containing $1 \%$ bovine serum albumin. Total cell counts were performed using a hemacytometer, and cytospins were prepared for differential cell counts by 


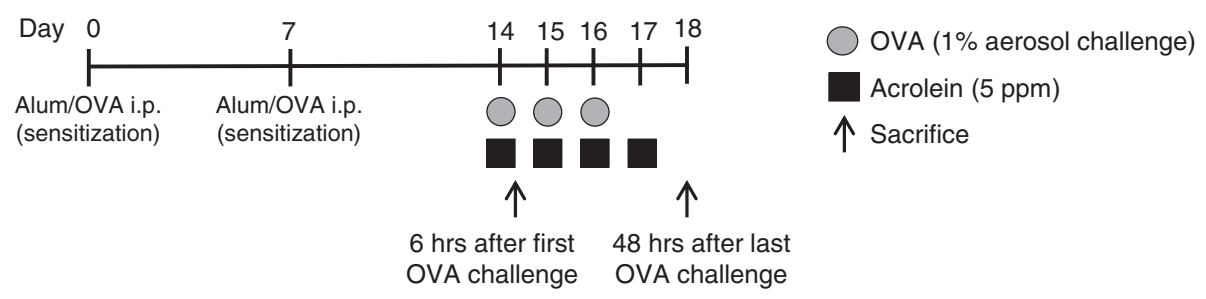

Figure 1 Schematic diagram of experimental design. Mice were sensitized to OVA by intraperitoneal injection on day 0 and 7, with $20 \mu \mathrm{g}$ OVA and the adjuvent aluminum hydroxide (Alum). Sham-sensitized mice received PBS in Alum. Mice were challenged with an aerosolized $1 \%$ OVA solution in sterile PBS for 30 min on days 14-16, immediately followed by exposure to acrolein ( 6 hrs; 5 ppm) on days 14-17. Mice were sacrificed on either day 14 (immediately after acrolein exposure; 6 hrs) or on day 18 (48 hrs after the final OVA challenge).

staining with a modified Wright-Giemsa stain (Protocol Hema 3, Fisher Diagnostics, Middletown, VA). At least 200 cells were counted per slide.

\section{Airway epithelial cell protein extraction by lysis lavage} Selective removal of airway epithelial cell proteins was performed as previously described [43] following a single OVA challenge and acrolein exposure on day 14 (Figure 1). Briefly, the trachea of each animal was cannulated, the alveolar regions of the lung were blocked by infusion of lowmelting-temperature agarose followed by $1 \%$ dextrose, and the excised lung was cooled to $4^{\circ} \mathrm{C}$, in $5 \%$ dextrose for $10 \mathrm{~min}$. The dextrose solution was then removed from the lungs through simultaneous inversion and gentle suction with a syringe, and was repeated until no more solution could be recovered. The airways were then lavaged with $0.5 \mathrm{~mL}$ lysis buffer containing $2 \mathrm{M}$ thiourea, $7 \mathrm{M}$ urea, $4 \%$ CHAPS, $1 \%$ Triton X-100 and 2\% Protease Inhibitor Cocktail III (Calbiochem) to recover airway epithelial cell proteins.

\section{Protein and RNA collection}

Following either BALF collection or lysis lavage, lungs were subsequently removed and two right lung lobes were snap frozen in liquid $\mathrm{N}_{2}$ for biochemical analysis, while one right lobe was placed in RNAlater (Ambion, Austin, TX) for $24 \mathrm{hrs}$ at $4^{\circ} \mathrm{C}$ before storage at $-80^{\circ} \mathrm{C}$ for subsequent RNA extraction.

\section{Lung histology}

The left lobe of the lungs was instilled with $4 \%$ paraformaldehyde in PBS for $10 \mathrm{~min}$ at a pressure of $25 \mathrm{~cm} \mathrm{H}_{2} \mathrm{O}$ and placed into $4 \%$ paraformaldehyde overnight for fixation of the tissue. Paraformaldehyde-fixed lung lobes were embedded in paraffin and cut into $5 \mu \mathrm{m}$ thick sections. Sections of paraffin-embedded lungs were deparaffinized and rehydrated to water.

\section{PAS staining and quantification}

Tissue sections were stained for mucus using the Periodic Acid-Schiff (PAS) method, and counterstained with hematoxylin. For quantification of mucus metaplasia, slides were scored using a scale of 0-4 (0 representing no reactivity and 4 being the highest intensity staining observed) for airway Periodic Acid-Schiff reactivity. Each slide was scored by two blinded individuals. The intensity was evaluated for each airway (at least 2) on each section from each animal, and averaged.

\section{$\mathrm{H} \& \mathrm{E}$ and immunofluorescence imaging}

Left lung lobes were processed for hematoxylin and eosin (H\&E) staining. Immunofluorescence (IF) staining of lung sections was performed with rabbit polyclonal anti-acrolein (Abcam; 1:500), rabbit anti-serum Club Cell (Clara Cell) Secretory Protein (CCSP; Millipore, Temecula, CA; 1:2000), and secondary antibody goat anti-rabbit Alexa 555 fluorescence conjugated IgG (Invitrogen; 1:500). For nuclear staining, specimens were treated with 4,6-diamidino-2phenylindole (DAPI). Sections were evaluated by confocal microscopy and analyzed using Metamorph imaging software (v.7.8.2.0; Molecular Devices, Sunnyvale, CA). Representative images of airways were selected for presentation.

\section{Analysis of cytokine levels}

The concentrations of IL-4, IL-13, TNF $\alpha$, and IL-12p40 were measured in lung lavage supernatants using ELISA, as recommended by the manufacturer (BD Biosciences, San Diego, CA).

\section{Quantitative reverse transcriptase polymerase chain reaction (RT-PCR)}

TRIzol (Invitrogen, Grand Island, NY) and a standard extraction protocol (Qiagen, Germantown, MD) were used to isolate total RNA from lung tissue. Total RNA was then treated with DNase (Qiagen, Valencia, CA) to remove contaminating DNA. Complementary DNA (cDNA) was prepared from $1 \mu \mathrm{g}$ of total RNA with MMLV reverse transcriptase and Oligo(dT)15 primer (Invitrogen). Quantitative RT-PCR was performed using SYBR Green PCR Supermix (Bio-Rad) and primers designed for various mouse genes (Table 1). GAPDH expression was used as a housekeeping gene and relative gene expression was calculated using the $2^{-\Delta \Delta C T}$ method [44]. 


\begin{tabular}{|c|c|c|}
\hline Gene & Sense $\left(5^{\prime}-3^{\prime}\right)$ & Antisense $\left(5^{\prime}-3^{\prime}\right)$ \\
\hline Muc5ac & AGTCTCTCTCCGCTCCTCTCAAT & CAGCCGAGAGGAGGGTTTGATC \\
\hline 114 & GGCATTTGAACGAGGTCAC & ATCGAAAAGCCCGAAAGAGT \\
\hline 1113 & AGGAGCTGAGCAACATCACA & GTGGGCTACTTCGATTTGG \\
\hline $1112 b$ & ACGGCCAGAGAAAAACTGAA & CTACCAAGGCACAGGGTCAT \\
\hline Tnf & TGGAAGACTCCTCCCAGGTA & ACGGCATGGATCTCAAAGAC \\
\hline Gclm & ACCTGGCCTCCTGCTGTGTG & GGTCGGTGAGCTGTGGGTGT \\
\hline
\end{tabular}

\section{Transcription factor activity assays}

Nuclear extracts were prepared using the Nuclear Extract Kit (Active Motif, Carlsbad, CA) for analysis of DNA binding activity of NF- $\mathrm{KB}$ or c-Jun with TransAM NF- $\kappa B$ p65 and TransAM AP-1 c-Jun ELISA kits, respectively (Active Motif, Carlsbad, CA).

\section{Identification of acrolein-modified proteins by biotin hydrazide labeling}

Frozen lung tissues were homogenized in lysis buffer (containing $50 \mathrm{mM}$ HEPES, $250 \mathrm{mM} \mathrm{NaCl}, 10 \%$ glycerol, $1 \%$ Triton X-100, $1.5 \mathrm{mM} \mathrm{MgCl} 2,1 \mathrm{mM}$ phenylmethylsulfonyl fluoride, $1 \mathrm{mM}$ EGTA, $2 \mathrm{mM} \mathrm{Na} \mathrm{VO}_{4}$, and $10 \mu \mathrm{g} / \mathrm{mL}$ of aprotinin and leupeptin) using a tissue homogenizer (Biospec Products, Racine, WI). A total of $300 \mu \mathrm{g}$ of protein was incubated for 2 hrs with constant mixing with $100 \mu \mathrm{L}$ of a $50 \mathrm{mM}$ solution of biotin hydrazide (Pierce) (in dimethyl sulfoxide (DMSO), $\mathrm{pH}$ 6.0) in a total volume of $200 \mu \mathrm{L}$. Samples were placed on ice and incubated for $1 \mathrm{hr}$ with $750 \mu \mathrm{L}$ of $30 \mathrm{mM} \mathrm{NaCNBH}_{4}$ in 1X PBS. Biotin labeled samples were washed 6 times with $300 \mu \mathrm{L}$ of $20 \mathrm{mM}$ Tris/Cl pH 7.4 and concentrated to $100 \mu \mathrm{L}$ in 3,000 MWCO filter devices (EMD Millipore, Billerica, MA). To this $100 \mu \mathrm{L}$ sample, $400 \mu \mathrm{L}$ of lysis buffer and $100 \mu \mathrm{L}$ of High Capacity Neutravidin beads were added and mixed constantly overnight at $4^{\circ} \mathrm{C}$. The beads were gently pelleted and washed 6 times with $1 \mathrm{~mL} 0.1 \mathrm{M}$ glycine, $\mathrm{pH}$ 2.8. Following a final wash with $1 \mathrm{~mL}$ of $20 \mathrm{mM}$ Tris/Cl pH 7.4, samples were boiled for $5 \mathrm{~min}$ at $100^{\circ} \mathrm{C}$ in $100 \mu \mathrm{L}$ of $2 \times$ reducing sample buffer (containing $0.125 \mathrm{M}$ Tris/Cl, 4\% SDS, 20\% glycerol, $0.47 \mathrm{M} \beta$ mercaptoethanol, $0.02 \%$ bromophenol blue, $\mathrm{pH}$ 6.8), and immediately centrifuged at $14,000 \mathrm{rpm}$ at $4^{\circ} \mathrm{C}$ for $5 \mathrm{~min}$, whereupon the supernatant containing the biotin-labeled proteins was collected for analysis by Western blotting.

\section{Analysis of protein thiol content by iodoacetamide-LC-biotin labeling}

Lysis lavage samples (100 $\mu \mathrm{g}$ protein) were washed $6 \mathrm{x}$ in 3000 MWCO centrifugation devices (Millipore) with $300 \mu \mathrm{L}$ deoxygenated lysis buffer $(50 \mathrm{mM}$ Tris- $\mathrm{HCl} \mathrm{pH}$ 7.4, $150 \mathrm{mM} \mathrm{NaCl}, 0.5 \%$ (vol/vol) Triton X-100 and 2\% protease inhibitor cocktail (Calbiochem)). Samples were concentrated to $100 \mu \mathrm{L}$ and then labeled with $100 \mu \mathrm{M}$ (final concentration) iodoacetamide-LC-biotin (Pierce) in DMSO. Samples were mixed for $1 \mathrm{hr}$ at room temp and then mixed 1:1 with $2 \times$ reducing sample buffer for Western blot analysis.

\section{Western blot and cellular GSH analysis}

Total lung homogenates, lysis lavage samples, or purified biotin-labeled proteins were analyzed by SDS-PAGE and Western blotting using antibodies against phosphorylated (p) IкB $\alpha$, p-cJun, cJun, JNK, IKK $\beta$, Nrf2 (D1Z9C) XP', Keap1 (Cell Signaling, Danvers, MA), IкB $\alpha$, RelA (Santa Cruz Biotechnology, Santa Cruz, CA), HO-1 (BioVision, Mountain View, CA; 1:1000), and $\beta$-actin (Sigma; 1:5000) and detected using HRP-conjugated secondary antibodies (Cell Signaling; 1:1000) or HRP-conjugated streptavidin (Sigma; 1:20,000) and enhanced chemiluminescence (Pierce). Lung homogenates were also used for analysis of reduced GSH [45].

\section{Statistical analysis}

All experiments were performed 2-3 times (with 3-4 animals per treatment group). Data are expressed as mean \pm SEM and were analyzed by ANOVA with Tukey correction for multiple comparisons. Results are considered statistically significant if $p<0.05$.

\section{Results}

Acrolein exposure suppresses allergen-induced pulmonary leukocyte infiltration and mucus production

To explore the effects of acrolein inhalation on allergic airway inflammation, we used an ovalbumin (OVA) model of asthma and exposed allergen-sensitized mice to acrolein vapor during the OVA challenge phase, and evaluated airway inflammation $48 \mathrm{hrs}$ after the final OVA challenge (Figure 1). As expected, OVA challenge of sensitized mice resulted in allergic inflammation, shown by increased numbers of primarily eosinophils, as well as neutrophils and lymphocytes in BAL fluids. Exposure to acrolein immediately following allergen challenge significantly suppressed these responses, shown by decreased total numbers of BAL cells (Figure 2A), and decreased numbers of eosinophils, neutrophils and lymphocytes (Figure 2B), compared with animals that were not exposed to acrolein. A trend towards suppression of allergen-induced pulmonary cell infiltration was also observed immediately after a single exposure to acrolein following a single OVA challenge (Figure $2 \mathrm{C}$ and $\mathrm{D}$ ), indicating acrolein may have direct and immediate effects on inflammatory pathways. Additionally, acrolein exposure markedly decreased allergen-induced mucus and goblet cell hyperplasia as detected by PAS staining (Figure $3 \mathrm{~A}$ and $\mathrm{B}$ ), and significantly decreased mRNA expression of the marker genes Muc5ac and Gob5 (Figure 3C), 48 hrs after the final OVA challenge. 

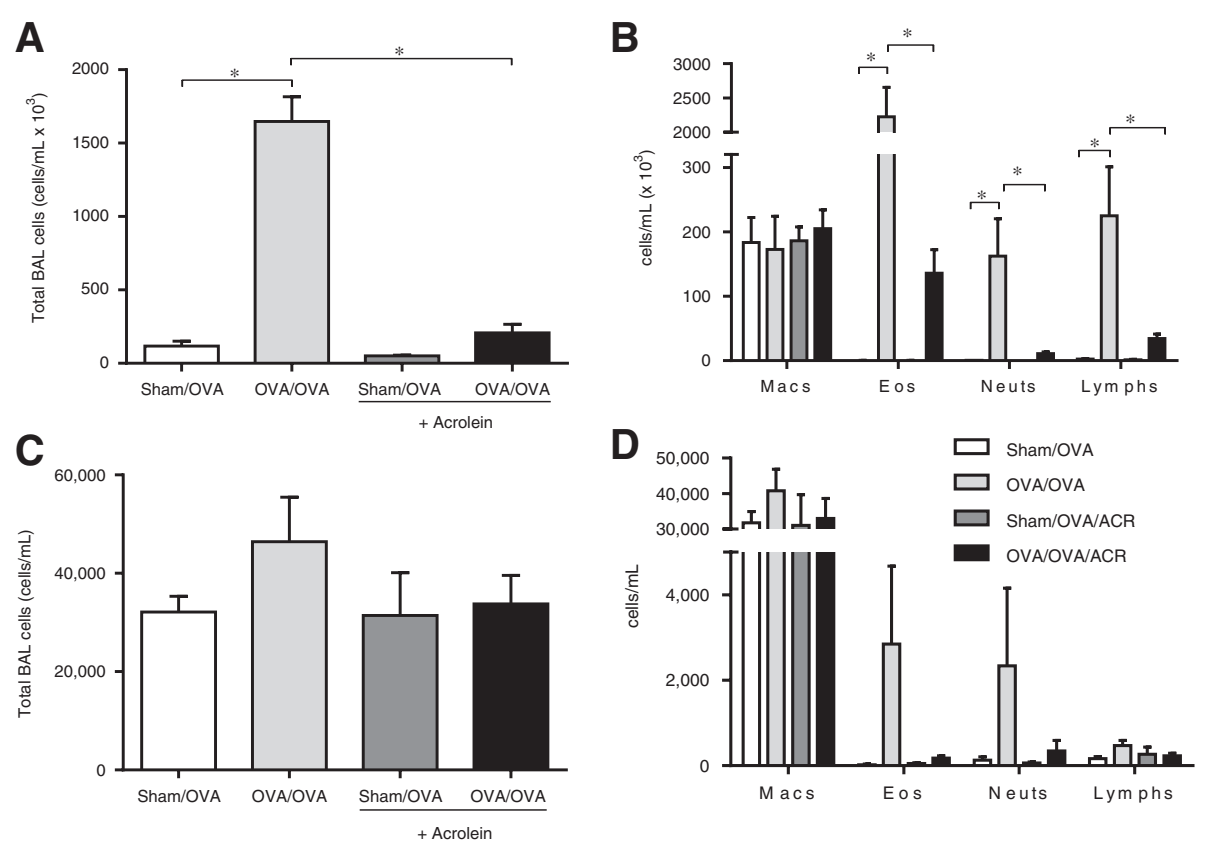

Figure 2 Acrolein exposure attenuates allergic airway inflammation in OVA-sensitized and challenged mice. C57BL/6 mice were sensitized and exposed as shown in Figure 1. Bronchoalveolar lavage fluid (BALF) was collected on day 18 (A,B) or 14 (6 hrs after OVA challenge; $\mathbf{C}, \mathbf{D})$ for enumeration of total cells $(\mathbf{A}, \mathbf{C})$ and differential cell counts $(\mathbf{B}, \mathbf{D})$. Results are expressed as mean $\pm \operatorname{SEM}(n=3-10 /$ group $)\left({ }^{*}, p<0.05\right)$.

Acrolein exposure significantly reduces lung cytokine expression and release after challenge

The reduced inflammation observed in antigen-challenged mice that were exposed to acrolein suggests an inhibition of pro-inflammatory cytokines responsible for inflammatory cell recruitment and mucus production. To determine whether acrolein exposure was affecting allergen-induced cytokine production, RT-PCR analysis of cytokine gene expression was performed on lung tissues harvested from animals 6 hrs after a single OVA challenge and/or a single 6-hr acrolein exposure (Table 2). As expected, OVA sensitization and challenge increased lung tissue expression of several

A

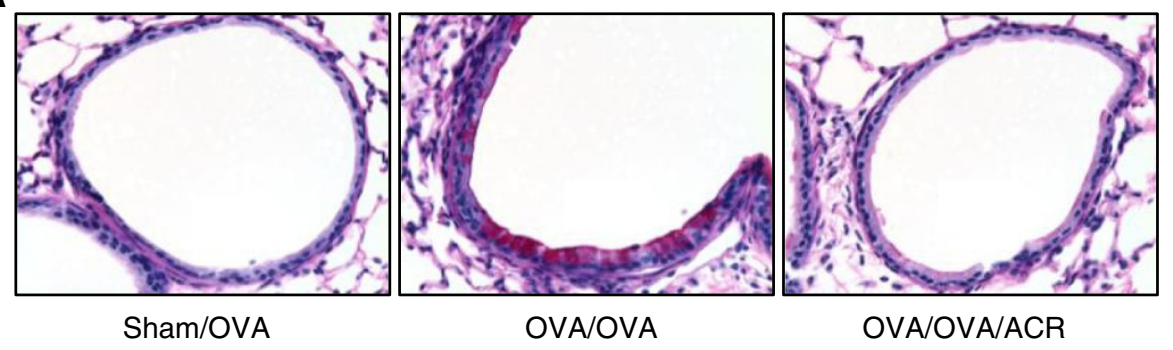

B

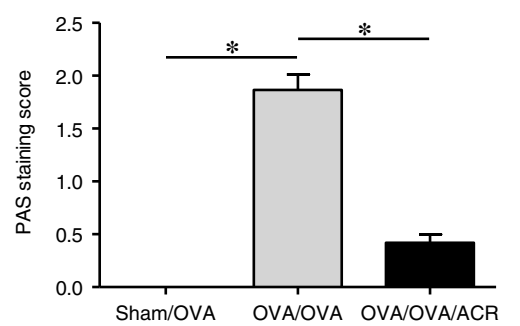

C

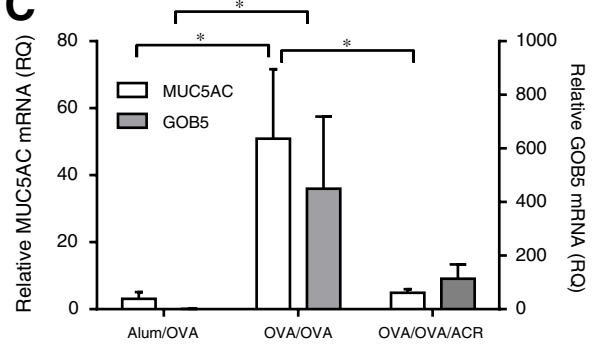

Figure 3 Acrolein exposure suppresses mucus/goblet cell hyperplasia in response to allergen challenge. Mucus/goblet cell hyperplasia was evaluated 48 hrs after the last OVA challenge by PAS staining (A) which was scored and quantified (B). Lung tissue mRNA gene expression of Muc5ac and Gob5 was analyzed by qRT-PCR (C). Results are expressed as mean \pm SEM ( $n=4 /$ group) (*, $p<0.05)$. 
Table 2 Effects of acrolein exposure on inflammatory cytokine mRNA expression from mouse lung homogenates 6 hrs after OVA challenge ${ }^{\dagger}$

\begin{tabular}{ccccc}
\hline Gene & Alum/OVA & OVA/OVA & Alum/OVA/ACR & OVA/OVA/ACR \\
\hline$\| 4$ & $1.00 \pm 0.20$ & $14.0 \pm 4.86^{*}$ & $0.94 \pm 0.29^{\#}$ & $5.76 \pm 1.42$ \\
$\| 13$ & $1.00 \pm 0.18$ & $8.91 \pm 2.47^{*}$ & $1.15 \pm 0.37^{\#}$ & $6.24 \pm 1.89$ \\
$\| 12 b$ & $1.00 \pm 0.17$ & $1.28 \pm 0.20$ & $0.74 \pm 0.09^{\#}$ & $0.51 \pm 0.08^{\#}$ \\
Tnf & $1.00 \pm 0.15$ & $2.46 \pm 0.23^{*}$ & $0.87 \pm 0.13^{\#}$ & $1.00 \pm 0.15^{\#}$
\end{tabular}

${ }^{\circ}$ Cytokine levels were measured by RT-PCR of lung homogenates from animals that were sensitized and challenged according to Figure 1. All values are normalized to Alum/OVA controls (mean $\pm S E M ; n=6-9$ mice/group) and ANOVA was used to compare groups ( ${ }^{*}, \mathrm{p}<0.05$ vs. Alum/OVA; $\#, \mathrm{p}<0.05$ vs OVA/OVA).

Th2 cytokines (Il4 and Il13), and these increases were attenuated following exposure to acrolein. OVA sensitization and challenge also increased expression of Tnf (encoding TNF $\alpha$ ), but did not significantly affect $I l 12 b$ (encoding IL-12p40). In both cases acrolein exposure significantly suppressed mRNA expression of these genes. Analysis of cytokine release into the airway lumen of animals, $48 \mathrm{hrs}$ after multiple OVA challenge, demonstrated a trend towards increased release of IL-4 and IL-13 in OVA-sensitized mice (Table 3), and acrolein exposure did not significantly affect IL-4 or IL-13 release in these animals. However, OVA sensitization and challenge resulted in a significant increase in IL-12p40 levels in BAL fluid, which was significantly attenuated following acrolein exposure (Table 3). Taken together, these results indicate that acrolein is most likely affecting pathways responsible for the recruitment of inflammatory cells and the mRNA expression and production of pro-inflammatory cytokines in this model of allergic inflammation.

Acrolein attenuates $\lg \mathrm{G} 1$ response to repeated OVA challenge To ensure that animals were sensitized to OVA, IgG1 ELISA was performed on serum from animals 48 hrs after the final OVA challenge (Figure 4A) or $6 \mathrm{hrs}$ after the first OVA challenge (Figure 4B). Indeed, all animals sensitized to OVA produced OVA-specific immunoglobulin. An attenuation of the IgG1 response was observed in acrolein exposed animals $48 \mathrm{hrs}$ after the final OVA challenge, but this was not observed in animals that only received a single OVA challenge and acrolein exposure.

Table 3 Effect of acrolein on Th1/Th2 cytokine levels in BAL fluids 48 hrs after OVA challenge ${ }^{\dagger}$

\begin{tabular}{cccc}
\hline & Alum/OVA & OVA/OVA & OVA/OVA/ACR \\
\hline IL-4 & $33.5 \pm 9.3$ & $68.6 \pm 27.0$ & $61.6 \pm 10.5$ \\
IL-13 & $69.9 \pm 28.2$ & $139.7 \pm 49.4$ & $100.5 \pm 16.1$ \\
IL-12p40 & $60.5 \pm 7.7$ & $600.4 \pm 66.9^{*}$ & $194.0 \pm 28.3^{\#}$ \\
TNFa & $146.3 \pm 41.6$ & $96.1 \pm 20.1$ & $191.6 \pm 47.6$ \\
\hline
\end{tabular}

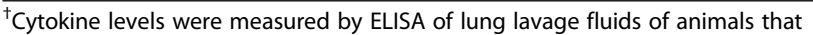
were sensitized and challenged according to Figure 1 . All values are expressed as $\mathrm{pg} / \mathrm{mL}$ (mean \pm SEM; $\mathrm{n}=5-10$ mice/group) and ANOVA was used to compare groups ( ${ }^{*}, \mathrm{p}<0.05$, vs. Alum/OVA; ${ }^{*}, \mathrm{p}<0.05$, vs OVA/OVA).
Acrolein exposure results in epithelial cell acrolein-adduct formation and disruption of thiol status

Our recent studies demonstrate that acrolein readily and directly interacts with numerous proteins in lung cells $[37,46]$. To confirm the adduction of inhaled acrolein to airway epithelial cell proteins, IF detection of acroleinbound protein was performed on lung sections and quantified using Metamorph software. Figure 5A demonstrates that acrolein exposure resulted in significantly increased levels of acrolein-adducted protein in conducting airway epithelial cells compared to controls. Since acrolein primarely reacts with cysteine residues [46], we analyzed the protein cysteine thiol content of lung epithelial cells following acrolein exposure using iodoacetamide-LC-biotin labeling. To this end, airway epithelial cell proteins were obtained by lysis lavage, and labeled with iodoacetamideLC-biotin to determine thiol content. Successful isolation of airway epithelial cells by lysis lavage was confirmed using both $H \& E$ and IF staining of lung sections (Additional file 1: Figure S1). Figure 5B reveals that acrolein exposure leads to a significant loss of epithelial cell protein thiol reactivity compared to non-acrolein exposed controls. The main mechanism of acrolein detoxification involves its conjugation to GSH, which can lead to disruption of cellular redox homeostasis, especially after acute exposure to high concentrations. Indeed, while OVA exposure of sensitized mice did not alter lung GSH status, acrolein exposure resulted in reduced lung tissue GSH levels when measured directly after acrolein exposure, especially in mice that were also challenged with OVA (Figure 5C). No such changes in lung tissue GSH were found $48 \mathrm{hrs}$ after OVA and/or acrolein exposures (results not shown), indicating that GSH depletion by acrolein is transient, and is restored by induction of GSH synthesis. Taken together, these results demonstrate that acrolein exposure leads to formation of acroleinadducts and an acute loss of both protein and non-protein thiols within airway epithelial cells.

\section{Acrolein exposure activates the Nrf2 pathway}

The transcription factor Nrf2 plays a key role in redox homeostasis by regulating the activation of glutathione synthesis and antioxidant defense genes, such as HO-1 [47]. To determine if Nrf2 was activated within the airway epithelium following acrolein exposure, lysis lavage samples from animals exposed to a single OVA challenge and acrolein exposure were analyzed for Nrf2-target protein HO-1. Indeed, acrolein exposure resulted in significant induction of HO-1 in airway epithelial cells (Figure 6A). Nrf2 also transcriptionally regulates the catalytic (Gclc) and regulatory $(\mathrm{Gclm})$ subunits of glutamate-cysteine ligase, the rate limiting enzyme in GSH synthesis [48] and acrolein exposure was found to increase lung tissue mRNA expression of Gclm and Gclc, reaching statistical significance in acrolein-exposed OVA/OVA mice vs non- 


\section{A}

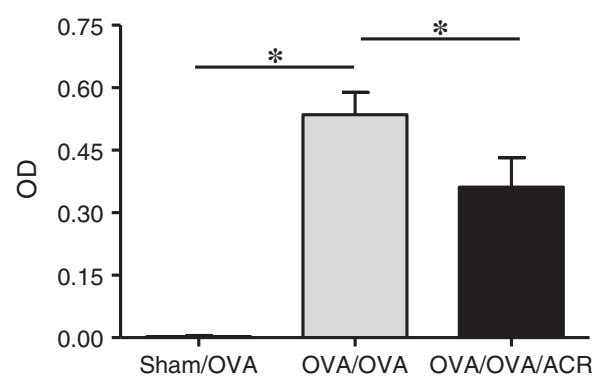

B

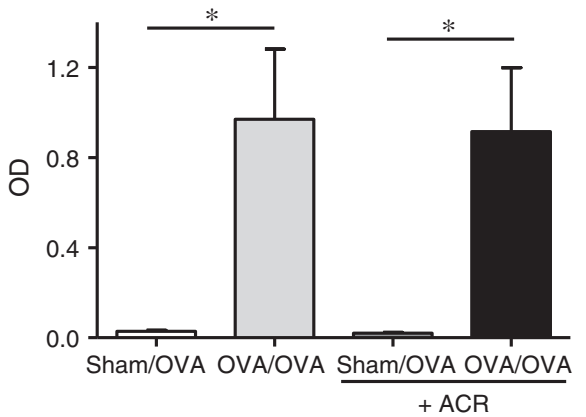

Figure 4 Acrolein exposure does not directly inhibit OVA-specific serum IgG1 production. Serum IgG1 was determined by ELISA on day 18 (48 hrs after final OVA challenge; $\mathbf{A}$ ) or day 14 (6 hrs after initial OVA challenge; B). Results are expressed as mean \pm SEM ( $n=4-6 /$ group) $\left({ }^{*}, p<0.05\right)$.

exposed OVA/OVA mice in case of Gclm (Figure 6B). We next determined Nrf2 protein accumulation in whole lung tissue lysates, as an indicator of Nrf2 activation, and observed significant increases in Nrf2 in lungs from acroleinexposed mice, in both sham- and OVA-sensitized animals (Figure 6C). Consistent with the observed accumulation and apparent activation of Nrf2, we observed increased carbonylation of Keap1 in lung homogenates following acrolein exposure as detected by biotin hydrazide labeling and Western blot analysis (Figure 6C), indicating direct alkylation of Keap1 by acrolein through Michael addition to its cysteine residues [49]. Interestingly, the extent of acrolein-induced Nrf2 accumulation and Keap1 alkylation appeared to be reduced in OVA-sensitized and challenged mice compared to sham-sensitized mice, although this did not reach statistical significance. Together, these results indicate that acrolein exposure results in alkylation of Keap1 and thereby leads to activation of the Nrf2 pathway in airway epithelial cells, resulting in increased expression of antioxidant and anti-inflammatory genes, which could contribute to the inhibitory effects of acrolein on OVAinduced allergic inflammation.

\section{Acrolein exposure inhibits allergen-induced activation of the NF-kB pathway}

OVA-induced inflammation requires the activation of the NF- $\mathrm{kB}$ and c-Jun N-terminal kinase (JNK)/AP-1 pathways, and both pathways were previously shown to be affected by components of cigarette smoke [34,37,50]. Analysis of phosphorylation of $\mathrm{I} \kappa \mathrm{B} \alpha$, the inhibitor of NF-kB, indicated significantly increased NF- $\mathrm{B}$ activation following OVA sensitization and challenge, and this was significantly attenuated following acrolein exposure (Figure 7A). Using DNA-binding activity assays on nuclear extracts from lung tissues, we evaluated the activation of NF- $\mathrm{kB} 6 \mathrm{hrs}$ after a single OVA challenge with or without acrolein exposure. As shown, although OVA challenge did not significantly enhance overall NF- $\mathrm{BB}$ activation, acrolein exposure inhibited NF- $\mathrm{KB}$ binding activity in both sensitized and sham mice (Figure 7B), demonstrating the ability of acrolein to inhibit NF- $\mathrm{kB}$ signaling. Activation of JNK signaling was evaluated by analysis of phosphorylation of c-Jun. Although OVA challenge did not significantly increase c-Jun phosphorylation above control levels, acrolein exposure tended to inhibit c-Jun phosphorylation in OVAchallenged mice (Figure 7C). Similarly, while OVA challenge did not significantly increase overall c-Jun nuclear DNA-binding activity, acrolein exposure tended to reduce its activity (Figure 7D). Collectively, these findings indicate that OVA challenge is associated with activation of NF- $\mathrm{kB}$ and perhaps JNK, and that acrolein exposure inhibits the NF- $\mathrm{kB}$ pathway, and also appears to inhibit the JNK pathway.

\section{Acrolein adduction of proteins within the NF-KB and JNK pathways}

Previous findings indicate that acrolein can inhibit NF$\mathrm{KB}$ and JNK signaling by direct alkylation of critical proteins associated with these pathways [33-35,37,51]. To address this possibility, we evaluated acrolein-induced protein carbonylation by Michael addition in lung homogenates of animals subjected to a single OVA challenge and/or acrolein exposure, using biotin hydrazide labeling and avidin purification of biotinylated proteins [52]. Indeed, acrolein exposure significantly increased detectable biotinylation within the NF- $\mathrm{kB}$ protein RelA in lungs of OVA-sensitized and challenged mice (Figure 8A), which may explain the decreased DNA binding activity observed in Figure 7B. Since acrolein exposure was found to inhibit OVA-induced phosphorylation of $\mathrm{I} \kappa \mathrm{B} \alpha$ (Figure 7A), we also determined whether acrolein exposure led to modification of IKB kinase beta $(\mathrm{IKK} \beta)$, the enzyme responsible for I $\mathrm{I} B \alpha$ phosphorylation. Acrolein exposure indeed led to significantly increased levels of biotin hydrazide-labeled IKK $\beta$ in lungs of OVAsensitized and challenged mice, indicating direct alkylation of this protein (Figure 8B). Similarly, as shown in Figure $8 \mathrm{C}$, increased amounts of biotin-labeled JNK 


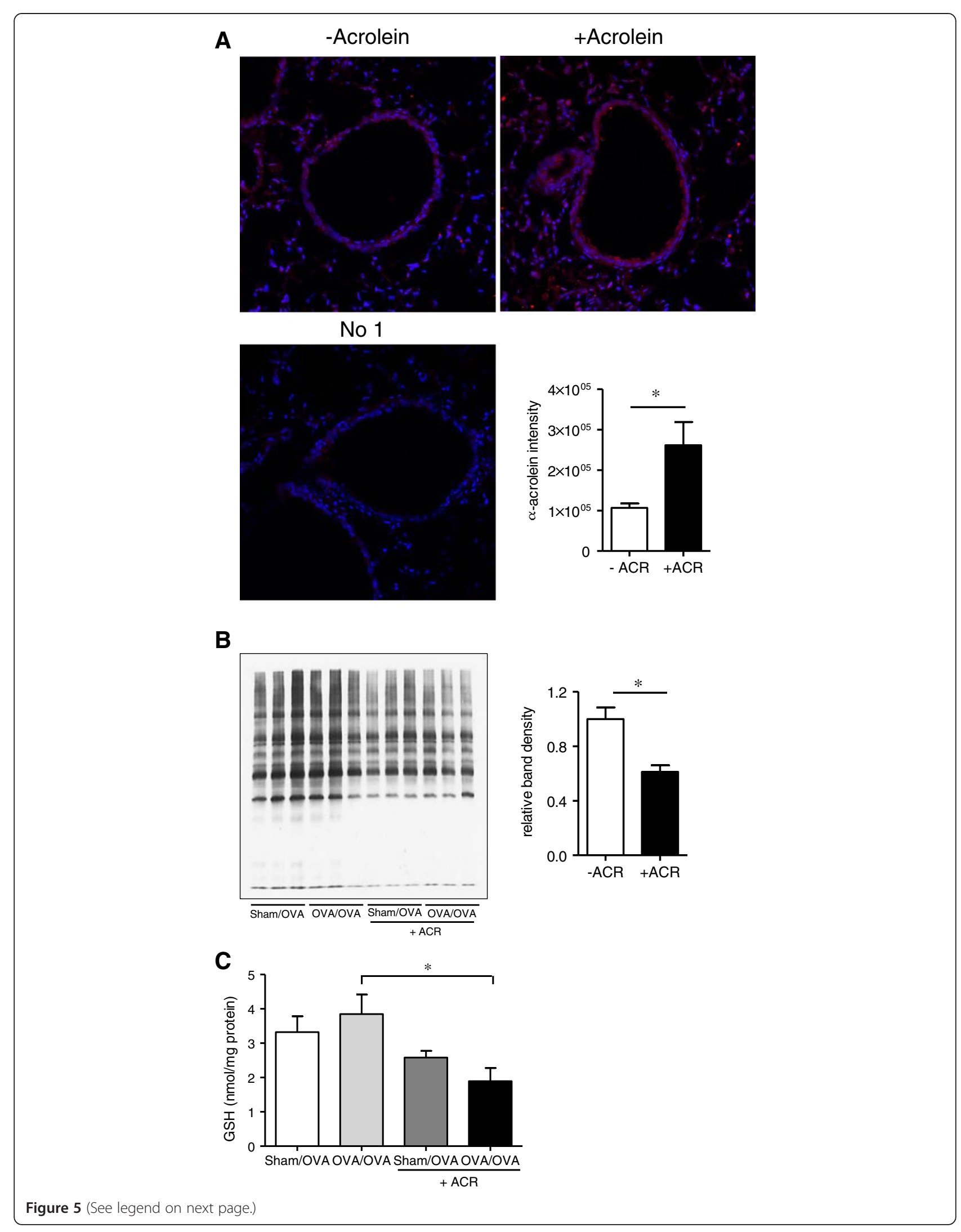


(See figure on previous page.)

Figure 5 Acrolein exposure induces protein-adduct formation and disruption of thiol status within the epithelium. (A) Lung sections were obtained 6 hrs after a single OVA challenge and acrolein exposure (day 14) and probed with anti-acrolein antibody (red) or DAPI (blue), and staining intensity was quantified using Metamorph software A control image without primary antibody (no $1{ }^{\circ}$ ) is shown to demonstrate specificity. (B) Epithelial proteins collected by lysis lavage were labeled with the cysteine-reactive probe lodoacetyl-LC-biotin, and biotin labeling was visualized by streptavidin blot and quantified using Image J software. (C) Reduced GSH was measured by HPLC in lung tissue homogenates. Results are expressed as mean \pm SEM ( $n=3-6 /$ group) (*, $p<0.05)$.

isoforms were detected in lung homogenates of animals that were exposed to both OVA and acrolein, which we recently associated with inhibition of JNK signaling [37]. Collectively, these findings suggest that the inhibitory effects of acrolein on the NF-KB and JNK pathways are at least partly due to direct modification by Michael addition of critical proteins within these pathways.

\section{Discussion}

It is well documented that tobacco smoke exposure can contribute to the development of allergic asthma [5,53], and can worsen asthma symptoms and enhance corticosteroid resistance $[54,55]$. However, a number of studies have also shown that smoke exposure suppresses some mediators of allergic inflammation such as eosinophilia $[16,17]$. The biochemical mechanisms by which cigarette smoking contributes to lung disease are highly complex, but various lines of evidence support an important role of reactive aldehydes, such as acrolein, found within cigarette smoke $[40,56]$. Indeed, acrolein exposure in rodent models can induce airways hyperresponsiveness [57] or mucus metaplasia [58,59], important hallmarks of asthma. In addition, based on previous studies demonstrating that acrolein exposure can suppress innate Th1-driven immune responses $[36,37,51]$, we speculated that such actions may promote Th2-polarized inflammatory responses during allergic inflammation. However, our present results indicate that acrolein exposure of allergen-sensitized mice immediately after allergen challenge significantly inhibits overall allergic airway inflammation, cytokine responses, and mucus metaplasia. Our findings are also consistent with a number of studies showing that exposure of OVAsensitized mice to CS both during and after OVA challenge suppresses eosinophilic inflammation and Th2 cytokine responses $[16,60]$, and imply that these anti-inflammatory effects of CS may in part be due to acrolein.

Acrolein exposure was found to suppress both Th1 cytokines (e.g. IL-12p40) and Th2 responses in the present

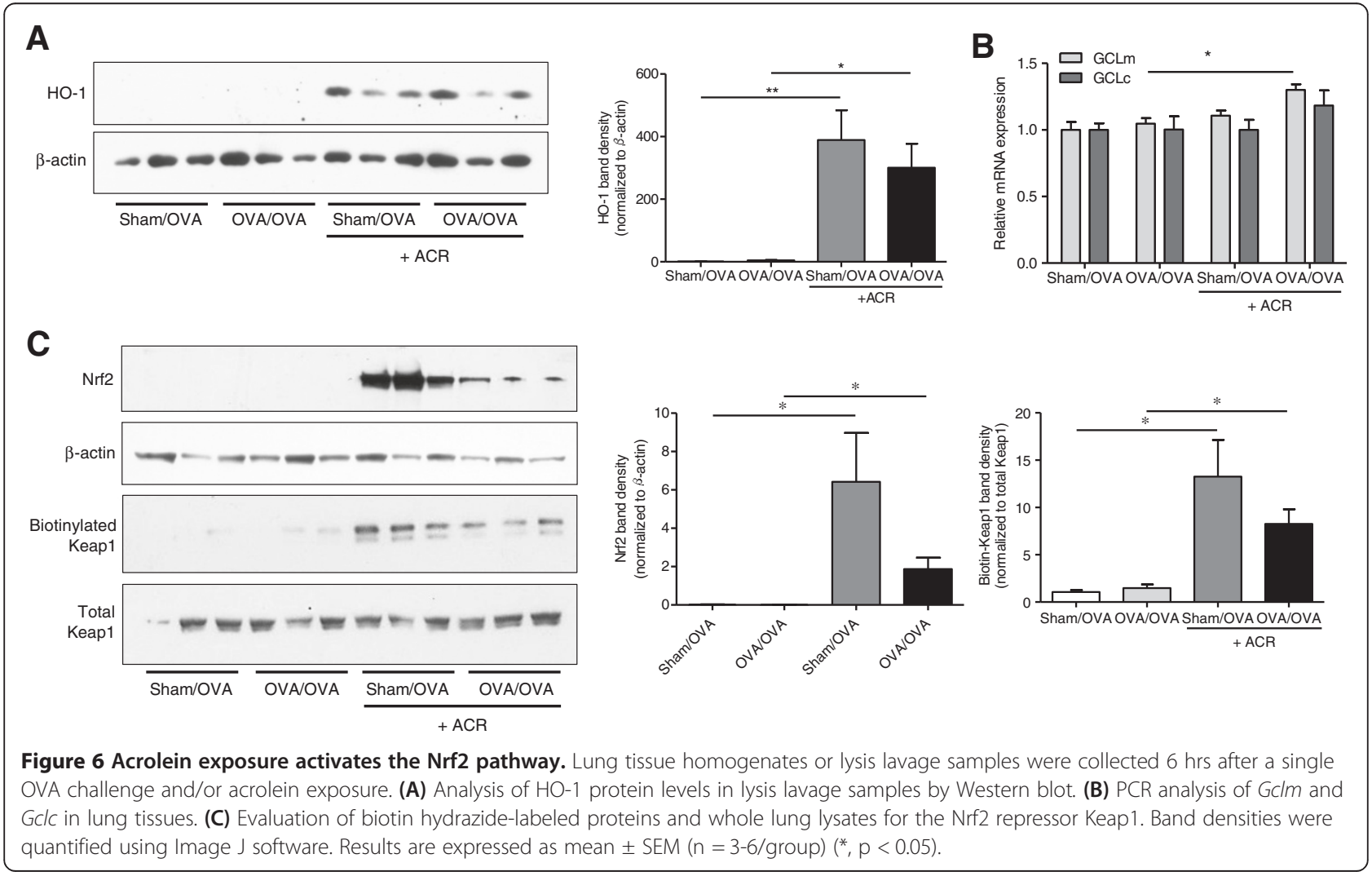




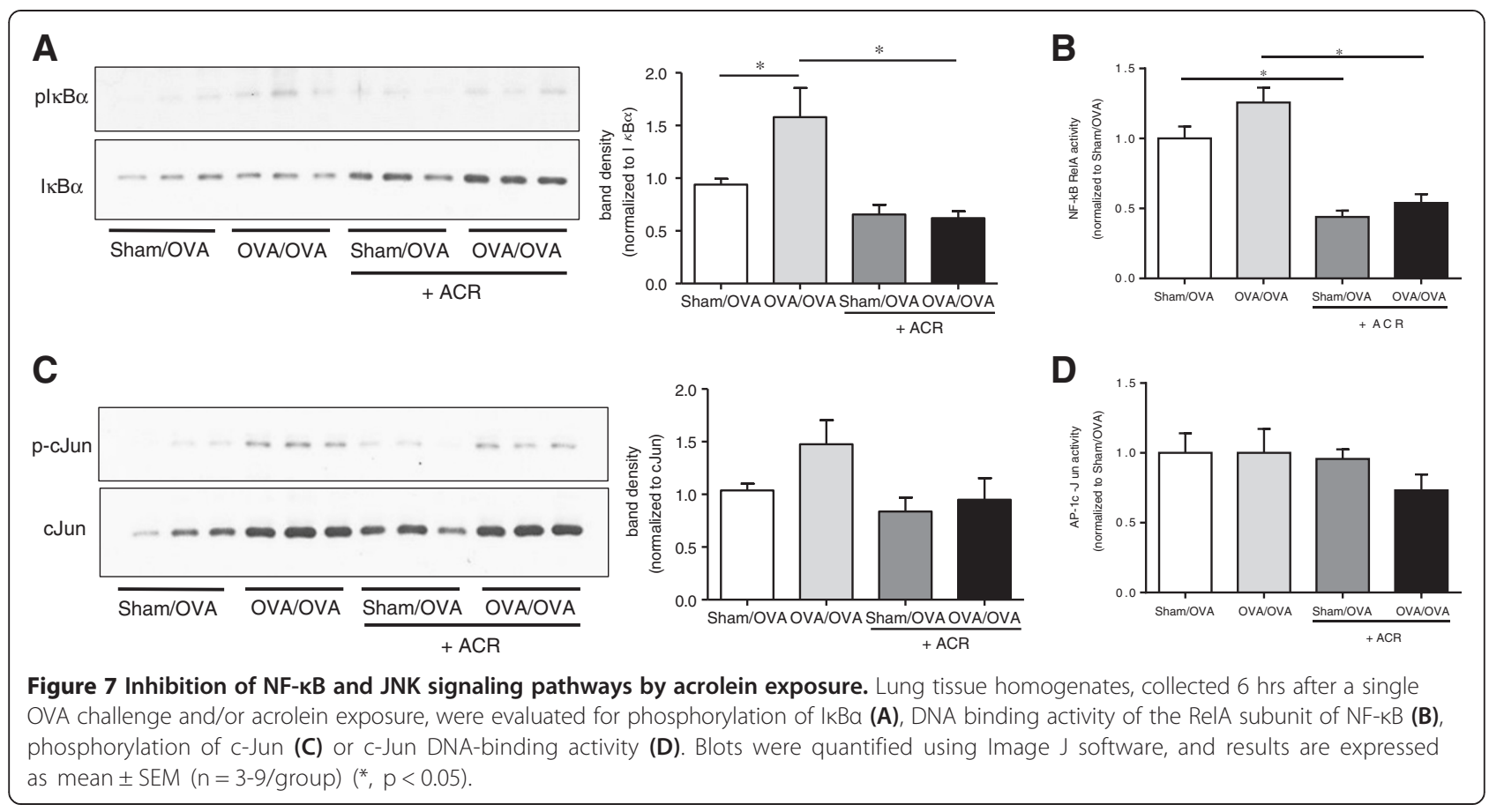

studies. Therefore, the observed suppression of allergic inflammation and mucus metaplasia were not due to Th2 suppression by activation of Th1 responses, but rather to its more general anti-inflammatory properties. Since the cytokine analysis was performed on BAL fluids, measured cytokines most likely originated primarily from alveolar macrophages, extravasated immune cells, and dendritic cells. Indeed, since dendritic cells may be a major source of IL-12p40, its reduction may reflect inhibited dendritic cell responses. Similarly, the suppressive effects on allergic inflammation may also be related to the ability of acrolein to inhibit $\mathrm{T}$ cell responses and proliferation [31].

Because of its strong chemical reactivity, our studies were focused on acute mechanisms by which acrolein affects critical processes involved in regulating airway inflammation. First, acrolein can stimulate anti-inflammatory responses by activating the Nrf2 pathway through direct interaction with redox-sensing cysteine residues within its inhibitor Keap1 [49]. Accordingly, our findings of increased alkylation of Keap1, accumulation of Nrf2 protein, and induction of the Nrf2-regulated genes HO-1 and GCL, indeed indicate the involvement of Nrf2 activation in response to acrolein exposure, and suggest that acrolein activates this pathway by direct modification of Keap1. However, acrolein may also activate Nrf2 by activating kinase signaling pathways to promote phosphorylation of Nrf2, critical for its migration into the nucleus and transcriptional activity [39]. The importance of Nrf2 in allergic inflammation has been addressed in studies with Nrf2deficient mice, which show enhanced inflammation and airway hyperresponsiveness in a similar OVA model of allergic asthma [61]. Additionally, Nrf2-deficient mice were also found to be more vulnerable to the oxidative and inflammatory effects of chronic cigarette smoke exposure [62]. Various reports indicate that severity of asthma or COPD is associated with impaired Nrf2 activation and function, due to chronic oxidative stress or post-translational modification of Nrf2 [63-65], and chemical activators of Nrf2, such as food-derived electrophilic compounds (e.g. sulforaphane, curcumin), are thought to have therapeutic benefit [39]. Our studies would suggest that acrolein might similarly suppress allergic inflammation, since it has anti-inflammatory properties similar to other electrophiles [37]. However, its chemical reactivity differs from many other anti-inflammatory electrophiles which may be responsible for its toxic properties or ability to promote inflammation or airways hyperresponsiveness $[41,66]$. Also, while acute exposure to cigarette smoke or acrolein might suppress inflammation due to Nrf2 activation, this may not apply to more chronic conditions in which the defensive capabilities of the Nrf2 pathway may be impaired.

Various lines of evidence indicate the importance of epithelial NF- $\mathrm{kB}$ in allergic airway inflammation, chemokine/cytokine-production and mucus metaplasia in allergic inflammation $[67,68]$, and a number of previous findings indicate that acrolein can suppress NF- $\mathrm{kB}$ signaling due to modification of redox-sensitive cysteine residues within this pathway $[33,34,36]$. Indeed, our present results indicate that acrolein exposure inhibits OVA-induced ІкB $\alpha$ phosphorylation and nuclear translocation of RelA, and we obtained direct evidence that 
A

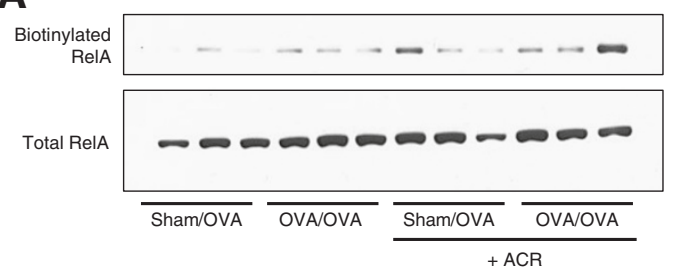

B
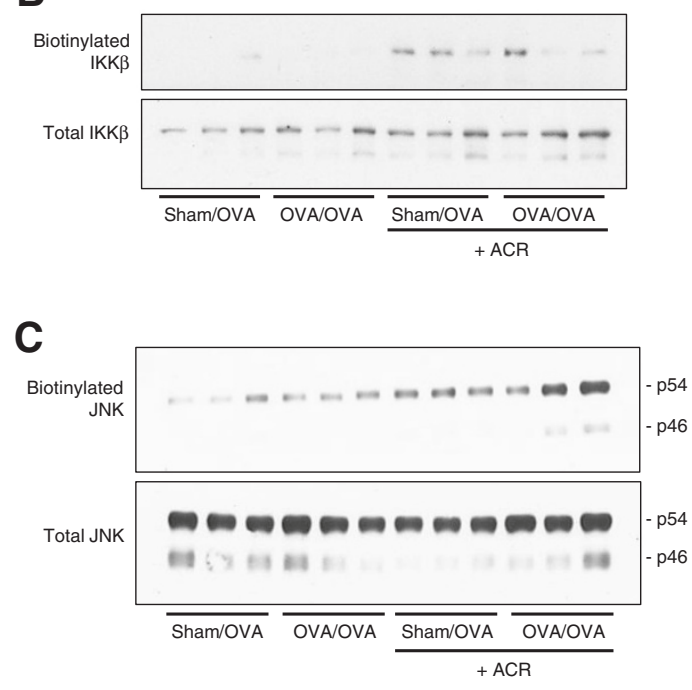
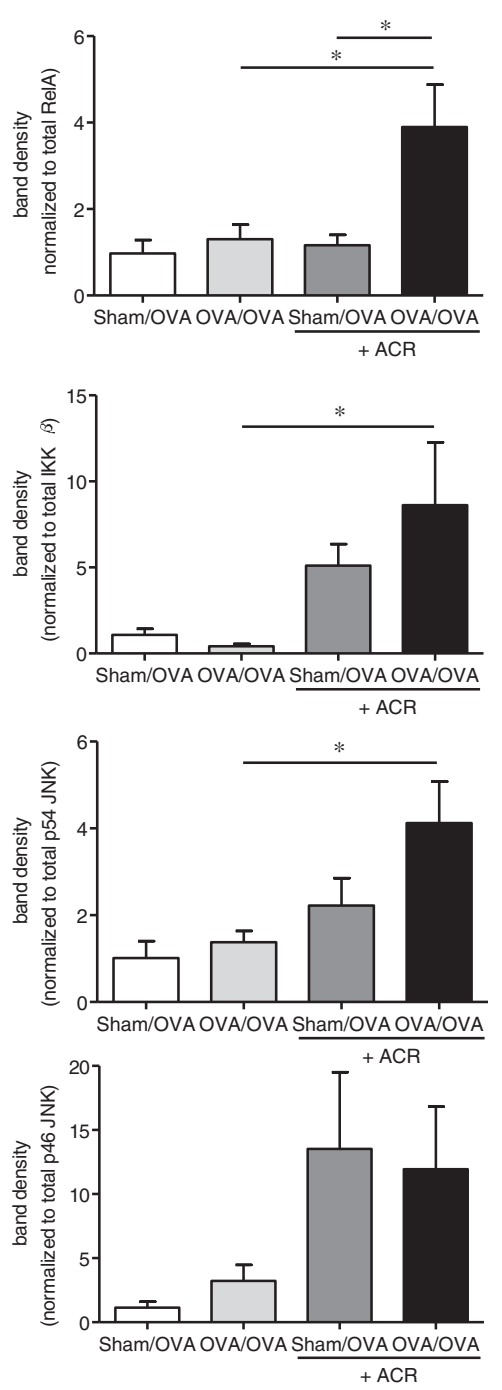

Figure 8 Acrolein adduction of proteins involved in NF-KB and JNK signaling. Lung tissue homogenates, collected 6 hrs after a single OVA challenge and/or acrolein exposure, were analyzed for carbonylated proteins by biotin hydrazide labeling and avidin purification. Purified biotinylated proteins were evaluated by Western blot for ReIA (A), IKKß (B) or JNK (C). Representative blots are shown. Band intensities were quantified using Image $J$ and expressed as mean \pm SEM ( $n=6 /$ group) $(*, p<0.05)$.

acrolein exposure led to increased carbonylation of both RelA and IKK $\beta$, suggesting their direct alkylation by acrolein, which is in accordance with previous studies [34,35,37,51]. Thus, acrolein exposure appears to suppress NF-KB signaling both at the level of IKK $\beta$, a critical redox-sensitive kinase within the NF- $\mathrm{kB}$ activation pathway [69], and at the level of RelA to inhibit its DNA binding activity [34].

Allergic inflammation may also involve activation of JNK [70] and AP-1 transcription factor family members, which regulate the expression of genes involved in a number of cellular functions including inflammation and pulmonary defense [71]. We previously demonstrated that acrolein can form adducts with specific cysteines within JNK2, which may play a prominent role in the immunosuppressive effects of acrolein [37]. Our present studies indicate that acrolein exposure increased alkylation of JNK isoforms, which was associated with apparent suppression of OVA-induced c-Jun phosphorylation and c-Jun DNA binding activity.

Taken together, our findings indicate that acrolein can suppress allergic airway inflammation by activating Nrf2 and inhibiting major inflammatory signaling pathways related to direct alkylation of critical redox-sensitive proteins in these pathways. It is important to emphasize that acrolein exposure does not suppress inflammation by a single specific mechanism, but by a combination of protein modifications that collectively result in antiinflammatory responses, due to activation of Nrf2 as well as inhibition of NF- $\mathrm{kB}$ and JNK signaling. This 
property is not unique to acrolein but is shared by many biologically relevant anti-inflammatory electrophiles, including suggested Nrf2 activators such as sulforaphane, that can also inhibit NF- $\mathrm{kB}$ and JNK signaling through direct modification of redox-sensitive cysteines [37]. In addition to these direct anti-inflammatory actions, acrolein exposure may also impact on allergic inflammation by more indirect systemic actions, such as the release of stress hormones such a corticosterone [72]. Although these anti-inflammatory actions of acrolein might be interpreted as protective in the context of inflammatory diseases such as asthma, it is prudent to point out that acrolein is reactive with a broader spectrum of biological targets compared to other anti-inflammatory electrophiles [66], and these alternative actions may be responsible for its significant toxic properties and adverse health effects and ability to induce airways hyperresponsiveness.

\section{Conclusions}

In summary, our studies indicate that acrolein may account for the reported anti-inflammatory effects of cigarette smoke in allergic asthma, and highlight multiple and diverse mechanisms by which acrolein exerts such anti-inflammatory actions, through inhibition of NF-kB and JNK pathways and activation of Nrf2 and subsequent anti-inflammatory gene induction. We believe that our findings are mostly relevant in the context of active smoking, which has sometimes been associated with improved asthma symptoms, and may in fact help explain the beneficial actions of the past use of "asthma cigarettes" in treating asthma symptoms (e.g. [73]). Moreover, our findings are also important in helping understand the alterations in inflammatory/immune processes within smokers with asthma, which may for a large part be due to the actions of acrolein. Future studies using acrolein-specific antibodies as a diagnostic tool will be instrumental in addressing the importance of acrolein in CS-related respiratory diseases, and may help assess the importance of acrolein-metabolizing enzymes, such as GSH S-transferase P1 [74], in asthma development or severity.

\section{Additional file}

Additional file 1: Figure S1. Isolation of airway epithelial cells by lysis lavage. Epithelial cells were selectively removed using the lysis lavage technique. Untreated lungs $(\boldsymbol{A}$ and $\mathbf{C}$ ) and lungs having undergone lysis lavage ( $B$ and $\mathbf{D})$ were stained with $\mathrm{H}$ and $\mathrm{E}(\mathbf{A}$ and $\mathbf{B})$ or immunofluorescence (C and D) for Club Cell (Clara Cell) Secretory Protein (CCSP) (red) and DAPI (blue).

\section{Abbreviations}

CS: Cigarette smoke; NF-kB: Nuclear factor-kappa B; AP-1: Activator protein-1; Keap 1: Kelch-like ECH-associated protein 1; Nrf2: Nuclear factor (erythroidderived 2)-like 2; HO-1: Heme oxygenase-1; GCL: Glutamate-cysteine ligase; GSH: Glutathione; i.p.: Intraperitoneally; OVA: Ovalbumin; PBS: Phosphate buffered saline; Alum: Aluminum hydroxide; ELISA: Enzyme-linked immune sorbent assay; PAS: Periodic acid Schiff; H\&E: Hematoxylin and eosin; IF: Immunofluorescence; CCSP: Club Cell (Clara Cell) Secretory Protein; DAPI: 4,6-diamidino-2-phenylindole; IL: Interleukin; DMSO: Dimethyl sulfoxide; JNK: c-Jun N-terminal kinase; IKK : IKB kinase beta.

\section{Competing interests}

The authors declare that they have no competing interests.

\section{Authors' contributions}

PCS participated in the design of the study, experimentation, performed statistical analysis and drafted the manuscript. DK participated in the design of the study, experimentation, performed statistical analysis, and critically revised the manuscript. AH carried out some of the mouse experiments, sample analyses and performed the immunostaining and microscopy. $\mathrm{MH}$ participated in the sample collection and analysis. MJR participated in the experimentation and sample collection. MEP participated in the interpretation of the data and critically revised the manuscript. AvdV contributed to conception of the study, participated in interpretation of the data and critically revised the manuscript. All authors read and approved the final manuscript.

\section{Acknowledgments}

This work has been supported by NIH (R01 grants HL085646 and ES021476) and Clinical Innovator Awards from the Flight Attendant Medical Research Institute (FAMRI) to AvdV and MEP. PCS was supported by a NIEHS postdoctoral training fellowship (T32 ES007122) and by a Young Clinical Scientist Award from FAMRI.

\section{Author details}

${ }^{1}$ Department of Pathology, College of Medicine, D205 Given Building, 89 Beaumont Ave, Burlington VT 05405, USA. ²Department of Medicine, University of Vermont, Burlington VT 05405, USA. ${ }^{3}$ Department of Environmental Health, Harvard School of Public Health, Boston 02115, MA, USA.

Received: 22 May 2013 Accepted: 8 October 2013 Published: 16 October 2013

\section{References}

1. Flodin U, Jonsson P, Ziegler J, Axelson O: An epidemiologic study of bronchial asthma and smoking. Epidemiology 1995, 6:503-505.

2. Rahman I, MacNee W: Lung glutathione and oxidative stress: implications in cigarette smoke-induced airway disease. Am J Physiol Lung 1999, 277:L1067-L1088.

3. Arcavi L, Benowitz NL: Cigarette smoking and infection. Arch Intern Med 2004, 164:2206-2216.

4. Sopori M: Effects of cigarette smoke on the immune system. Nat Rev Immunol 2002, 2:372-377.

5. Floreani AA, Rennard SI: The role of cigarette smoke in the pathogenesis of asthma and as a trigger for acute symptoms. Curr Opin Pulm Med 1999, 5:38-46.

6. Herr C, Beisswenger C, Hess C, Kandler K, Suttorp N, Welte T, Schroeder JM, Vogelmeier C: Suppression of pulmonary innate host defence in smokers. Thorax 2009, 64:144-149.

7. Sethi S, Evans N, Grant BJ, Murphy TF: New strains of bacteria and exacerbations of chronic obstructive pulmonary disease. $N$ Engl J Med 2002, 347:465-471

8. Difranza JR, Aligne CA, Weitzman M: Prenatal and postnatal environmental tobacco smoke exposure and children's health. Pediatrics 2004, 113:1007-1015.

9. Gilliland FD, Li YF, Dubeau L, Berhane K, Avol E, McConnell R, Gauderman WJ, Peters JM: Effects of glutathione S-transferase M1, maternal smoking during pregnancy, and environmental tobacco smoke on asthma and wheezing in children. Am J Respir Crit Care Med 2002, 166:457-463.

10. Kabesch M, Hoefler C, Carr D, Leupold W, Weiland SK, Von Mutius E: Glutathione $S$ transferase deficiency and passive smoking increase childhood asthma. Thorax 2004, 59:569-573.

11. Hjern A, Hedberg A, Haglund B, Rosen M: Does tobacco smoke prevent atopic disorders? A study of two generations of Swedish residents. Clin Exp Allergy 2001, 31:908-914. 
12. Troisi RJ, Speizer FE, Rosner B, Trichopoulos D, Willett WC: Cigarette smoking and incidence of chronic bronchitis and asthma in women. Chest 1995, 108:1557-1561.

13. Moerloose KB, Pauwels RA, Joos GF: Short-term cigarette smoke exposure enhances allergic airway inflammation in mice. Am J Respir Crit Care Med 2005, 172:168-172.

14. Rumold R, Jyrala M, Diaz-Sanchez D: Secondhand smoke induces allergic sensitization in mice. J Immunol 2001, 167:4765-4770.

15. Seymour BW, Pinkerton KE, Friebertshauser KE, Coffman RL, Gershwin LJ: Second-hand smoke is an adjuvant for $\mathrm{T}$ helper-2 responses in a murine model of allergy. J Immunol 1997, 159:6169-6175.

16. Melgert BN, Postma DS, Geerlings M, Luinge MA, Klok PA, van der Strate BW, Kerstjens HA, Timens W, Hylkema MN: Short-term smoke exposure attenuates ovalbumin-induced airway inflammation in allergic mice. Am J Respir Cell Mol Biol 2004, 30:880-885.

17. Robbins CS, Pouladi MA, Fattouh R, Dawe DE, Vujicic N, Richards CD, Jordana M, Inman MD, Stampfli MR: Mainstream cigarette smoke exposure attenuates airway immune inflammatory responses to surrogate and common environmental allergens in mice, despite evidence of increased systemic sensitization. J Immunol 2005, 175:2834-2842.

18. Thatcher TH, Benson RP, Phipps RP, Sime PJ: High-dose but not low-dose mainstream cigarette smoke suppresses allergic airway inflammation by inhibiting T cell function. Am J Physiol Lung Cell Mol Physiol 2008, 295:L412-L421.

19. Trimble NJ, Botelho FM, Bauer CM, Fattouh R, Stampfli MR: Adjuvant and anti-inflammatory properties of cigarette smoke in murine allergic airway inflammation. Am J Respir Cell Mol Biol 2009, 40:38-46.

20. Hodge S, Matthews G, Mukaro V, Ahern J, Shivam A, Hodge G, Holmes M, Jersmann H, Reynolds PN: Cigarette smoke-induced changes to alveolar macrophage phenotype and function are improved by treatment with procysteine. Am J Respir Cell Mol Biol 2011, 44:673-681.

21. Kroening PR, Barnes TW, Pease L, Limper A, Kita H, Vassallo R: Cigarette smoke-induced oxidative stress suppresses generation of dendritic cell IL-12 and IL-23 through ERK-dependent pathways. J Immuno/ 2008, 181:1536-1547.

22. Reddy S, Finkelstein El, Wong PS-Y, Phyng A, Cross CE, van der Vliet A: Indentification of glutathione modifications by cigarette smoke. Free Radic Biol Med 2002, 33:1490-1498.

23. Esterbauer $\mathrm{H}$, Schaur RJ, Zollner $\mathrm{H}$ : Chemistry and biochemistry of 4-hydroxynonenal, malonaldehyde and related aldehydes. Free Radic Biol Med 1991, 11:81-128.

24. Muller T, Gebel $\mathrm{S}$ : The cellular stress response induced by aqueous extracts of cigarette smoke is critically dependent on the intracellular glutathione concentration. Carcinogenesis 1998, 19:797-801.

25. Andreoli R, Manini P, Corradi M, Mutti A, Niessen WM: Determination of patterns of biologically relevant aldehydes in exhaled breath condensate of healthy subjects by liquid chromatography/atmospheric chemical ionization tandem mass spectrometry. Rapid Commun Mass Spectrom 2003, 17:637-645.

26. Annovazzi L, Cattaneo V, Viglio S, Perani E, Zanone C, Rota C, Pecora F, Cetta G, Silvestri M, ladarola P: High-performance liquid chromatography and capillary electrophoresis: methodological challenges for the determination of biologically relevant low-aliphatic aldehydes in human saliva. Electrophoresis 2004, 25:1255-1263.

27. Kilburn KH, McKenzie WN: Leukocyte recruitment to airways by aldehydecarbon combinations that mimic cigarette smoke. Lab Invest 1978, 38:134-142.

28. Leach CL, Hatoum NS, Ratajczak HV, Gerhart JM: The pathologic and immunologic effects of inhaled acrolein in rats. Toxicol Lett 1987, 39:189-198.

29. Li L, Holian A: Acrolein: a respiratory toxin that suppresses pulmonary host defense. Rev Environ Health 1998, 13:99-108.

30. Kirkham PA, Spooner G, Rahman I, Rossi AG: Macrophage phagocytosis of apoptotic neutrophils is compromised by matrix proteins modified by cigarette smoke and lipid peroxidation products. Biochem Biophys Res Commun 2004, 318:32-37.

31. Lambert C, McCue J, Portas M, Ouyang Y, Li J, Rosano TG, Lazis A, Freed BM: Acrolein in cigarette smoke inhibits T-cell responses. J Allergy Clin Immunol 2005, 116:916-922.

32. Kehrer JP, Biswal SS: The molecular effects of acrolein. Toxicol Sci 2000, 57:6-15.

33. Horton ND, Biswal SS, Corrigan LL, Bratta J, Kehrer JP: Acrolein causes inhibitor kappaB-independent decreases in nuclear factor kappaB activation in human lung adenocarcinoma (A549) cells. J Biol Chem 1999, 274:9200-9206.
34. Lambert C, Li J, Jonscher K, Yang T-C, Reigan P, Quintana M, Harvey J, Freed BM: Acrolein inhibits cytokine gene expression by alkylating cysteine and arginine residues in the NF-KB1 DNA binding domain. $J$ Biol Chem 2007, 282:19666-19675.

35. Valacchi G, Pagnin E, Phung A, Nardini M, Schock BC, Cross CE, van der Vliet A: Inhibition of NFkappaB activation and IL-8 expression in human bronchial epithelial cells by acrolein. Antioxid Redox Signal 2005, 7:25-31.

36. Kasahara DI, Poynter ME, Othman Z, Hemenway D, van der Vliet A: Acrolein inhalation suppresses lipopolysaccharide-induced inflammatory cytokine production but does not affect acute airways neutrophilia. J Immunol 2008, 181:736-745

37. Hristova M, Spiess PC, Kasahara DI, Randall MJ, Deng B, van der Vliet A: The tobacco smoke component, acrolein, suppresses innate macrophage responses by direct alkylation of c-Jun N-terminal kinase. Am J Respir Cell Mol Biol 2012, 46:23-33.

38. Na HK, Surh YJ: Transcriptional regulation via cysteine thiol modification: a novel molecular strategy for chemoprevention and cytoprotection. Mol Carcinog 2006, 45:368-380

39. Hybertson BM, Gao B, Bose SK, McCord JM: Oxidative stress in health and disease: the therapeutic potential of Nrf2 activation. Mol Aspects Med 2011, 32:234-246.

40. Leikauf GD: Hazardous air pollutants and asthma. Environ Health Perspect 2002, 110(Suppl 4):505-526.

41. Bein K, Leikauf GD: Acrolein - a pulmonary hazard. Mol Nutr Food Res 2011, 55:1342-1360.

42. Bevelander M, Mayette J, Whittaker LA, Paveglio SA, Jones CC, Robbins J, Hemenway D, Akira S, Uematsu S, Poynter ME: Nitrogen dioxide promotes allergic sensitization to inhaled antigen. J Immunol 2007, 179:3680-3688.

43. Wheelock AM, Zhang L, Tran M-U, Morin D, Penn S, Buckpitt AR, Plopper CG: Isolation of rodent airway epithelial cell proteins facilitates in vivo proteomics studies of lung toxicity. Am J Physiol Lung Cell Mol Physiol 2004, 286:L399-L410.

44. Livak KJ, Schmittgen TD: Analysis of relative gene expression data using real-time quantitative PCR and the 2(-Delta Delta C(T)) Method. Methods 2001, 25:402-408.

45. Finkelstein El, Ruben J, Koot CW, Hristova M, van der Vliet A: Regulation of constitutive neutrophil apoptosis by the $a, \beta$-unsaturated aldehydes acrolein and 4-hydroxynonenal. Am J Physiol Lung Cell Mol Physiol 2005, 289:L1019-L1028.

46. Spiess PC, Deng B, Hondal RJ, Matthews DE, van der Vliet A: Proteomic profiling of acrolein adducts in human lung epithelial cells. J Proteomics 2011, 74:2380-2394.

47. Cho HY, Reddy SP, Kleeberger SR: Nrf2 defends the lung from oxidative stress. Antioxid Redox Signal 2006, 8:76-87.

48. Lu SC: Regulation of glutathione synthesis. Mol Aspects Med 2009, 30:42-59.

49. McMahon M, Lamont DJ, Beattie KA, Hayes JD: Keap1 perceives stress via three sensors for the endogenous signaling molecules nitric oxide, zinc, and alkenals. Proc Natl Acad Sci U S A 2010, 107:18838-18843.

50. Manzel LJ, Shi L, O'Shaughnessy PT, Thorne PS, Look DC: Inhibition by cigarette smoke of nuclear factor-kappaB-dependent response to bacteria in the airway. Am J Respir Cell Mol Biol 2011, 44:155-165.

51. Li L, Hamilton RF Jr, Holian A: Effect of acrolein on human alveolar macrophage NF-kappaB activity. Am J Physiol 1999, 277:L550-L557.

52. Hristova M, Heuvelmans $S$, van der Vliet A: GSH-dependent regulation of Fas-mediated caspase-8 activation by acrolein. FEBS Lett 2007, 581:361-367.

53. Polosa R, Knoke JD, Russo C, Piccillo G, Caponnetto P, Sarva M, Proietti L, Al-Delaimy WK: Cigarette smoking is associated with a greater risk of incident asthma in allergic rhinitis. J Allergy Clin Immunol 2008, 121:1428-1434.

54. Chalmers GW, Macleod KJ, Little SA, Thomson LJ, McSharry CP, Thomson NC: Influence of cigarette smoking on inhaled corticosteroid treatment in mild asthma. Thorax 2002, 57:226-230.

55. Kerstjens HA, Overbeek SE, Schouten JP, Brand PL, Postma DS: Airways hyperresponsiveness, bronchodilator response, allergy and smoking predict improvement in FEV1 during long-term inhaled corticosteroid treatment. Dutch CNSLD Study Group. Eur Respir J 1993, 6:868-876.

56. Moretto N, Volpi G, Pastore F, Facchinetti F: Acrolein effects in pulmonary cells: relevance to chronic obstructive pulmonary disease. Ann N Y Acad Sci 2012, 1259:39-46.

57. Leikauf GD, Leming LM, O'Donnell JR, Doupnik CA: Bronchial responsiveness and inflammation in guinea pigs exposed to acrolein. J Appl Physiol 1989, 66:171-178. 
58. Borchers MT, Wert SE, Leikauf GD: Acrolein-induced MUC5ac expression in rat airways. Am J Physiol Lung Cell Mol Physiol 1998, 18:L573-L581.

59. Borchers MT, Wesselkamper S, Wert SE, Shapiro SD, Leikauf GD: Monocyte inflammation augments acrolein-induced Muc5ac expression in mouse lung. Am J Physiol Lung Cell Mol Physiol 1999, 277:L489-L497.

60. Hizume DC, Toledo AC, Moriya HT, Saraiva-Romanholo BM, Almeida FM, Arantes-Costa FM, Vieira RP, Dolhnikoff M, Kasahara DI, Martins MA: Cigarette smoke dissociates inflammation and lung remodeling in OVA-sensitized and challenged mice. Respir Physiol Neurobiol 2012, 181:167-176.

61. Rangasamy T, Guo J, Mitzner WA, Roman J, Singh A, Fryer AD, Yamamoto M, Kensler TW, Tuder RM, Georas SN, Biswal S: Disruption of Nrf2 enhances susceptibility to severe airway inflammation and asthma in mice. J Exp Med 2005, 202:47-59.

62. Rangasamy T, Cho CY, Thimmulappa RK, Zhen L, Srisuma SS, Kensler TW, Yamamoto M, Petrache I, Tuder RM, Biswal S: Genetic ablation of Nrf2 enhances susceptibility to cigarette smoke-induced emphysema in mice. J Clin Invest 2004, 114:1248-1259.

63. Fitzpatrick AM, Stephenson ST, Hadley GR, Burwell L, Penugonda M, Simon DM, Hansen J, Jones DP, Brown LA: Thiol redox disturbances in children with severe asthma are associated with posttranslational modification of the transcription factor nuclear factor (erythroid-derived 2)-like 2. J Allergy Clin Immunol 2011, 127:1604-1611.

64. Malhotra D, Thimmulappa R, Navas-Acien A, Sandford A, Elliott M, Singh A, Chen L, Zhuang X, Hogg J, Pare P, et al: Decline in NRF2-regulated antioxidants in chronic obstructive pulmonary disease lungs due to loss of its positive regulator, DJ-1. Am J Respir Crit Care Med 2008, 178:592-604.

65. Suzuki M, Betsuyaku T, Ito Y, Nagai K, Nasuhara Y, Kaga K, Kondo S, Nishimura M: Down-regulated NF-E2-related factor 2 in pulmonary macrophages of aged smokers and patients with chronic obstructive pulmonary disease. Am J Respir Cell Mol Biol 2008, 39:673-682.

66. Higdon A, Diers AR, Oh JY, Landar A, Darley-Usmar VM: Cell signalling by reactive lipid species: new concepts and molecular mechanisms. Biochem J 2012, 442:453-464

67. Poynter ME, Cloots R, Van Woerkom T, Butnor KJ, Vacek P, Taatjes DJ, Irvin CG, Janssen-Heininger YM: NF-kappa B activation in airways modulates allergic inflammation but not hyperresponsiveness. J Immunol 2004, 173:7003-7009.

68. Poynter ME, Irvin CG, Janssen-Heininger YM: Rapid activation of nuclear factor-kappaB in airway epithelium in a murine model of allergic airway inflammation. Am J Pathol 2002, 160:1325-1334.

69. Janssen-Heininger YM, Poynter ME, Aesif SW, Pantano C, Ather JL, Reynaert NL, Ckless K, Anathy V, van der Velden J, Irvin CG, van der Vliet A: Nuclear factor kappaB, airway epithelium, and asthma: avenues for redox control. Proc Am Thorac Soc 2009, 6:249-255.

70. Davis RJ: Signal transduction by the JNK group of MAP kinases. Cell 2000, 103:239-252.

71. Shaulian E, Karin M: AP-1 in cell proliferation and survival. Oncogene 2001, 20:2390-2400

72. Warholm M, Holmberg B, Hogberg J, Kronevi T, Gotharson A: The acute effects of single and repeated injections of acrolein and other aldehydes. Int J Tissue React 1984, 6:61-70.

73. Herxheimer $\mathrm{H}$ : Atropine cigarettes in asthma and emphysema. Br Med J 1959, 2:167-171.

74. Tamer L, Calikoglu M, Ates NA, Yildirim H, Ercan B, Saritas E, Unlu A, Atik U: Glutathione-S-transferase gene polymorphisms (GSTT1, GSTM1, GSTP1) as increased risk factors for asthma. Respirology 2004, 9:493-498.

\section{Submit your next manuscript to BioMed Central and take full advantage of:}

- Convenient online submission

- Thorough peer review

- No space constraints or color figure charges

- Immediate publication on acceptance

- Inclusion in PubMed, CAS, Scopus and Google Scholar

- Research which is freely available for redistribution

Submit your manuscript at www.biomedcentral.com/submit
Ciomed Central 